\title{
Food banking and emergency food aid: expanding the definition of local food environments and systems
}

\author{
Claire Thompson ${ }^{1 *}$, Dianna Smith ${ }^{2}$ and Steven Cummins ${ }^{1}$
}

\begin{abstract}
If current trends in food insecurity continue then the diets of low-income people may become characterised by the inclusion of significant amounts of donated and surplus food accessed via the third-sector. These developments have yet to be integrated into macro models and concepts of the food environment. Addressing this caveat is necessary in order to both help build an evidence base to challenge policies that exacerbate the drivers of food insecurity and to inform interventions aimed at improving the diets of disadvantaged populations.
\end{abstract}

Keywords: Food insecurity, Food environments, Food aid outlets

Food environments are the collective physical, economic, policy and socio-cultural conditions that influence food and beverage choices and nutritional status [1]. In terms of conceptualising pathways to diet-led health inequalities, landscape metaphors of food deserts, food swamps and food brownfields provide a critical lens for pathologising food environments and systems in low-income and food insecure neighbourhoods [2]. 'Unhealthy' food environments are increasingly understood as symptomatic of the interacting pathologies of household poverty, community disadvantage, and the actions of the food industry. Thus, household food insecurity can be understood as an outcome of interrelated social, commercial and economic conditions [3]. While, in this respect, food environments research offers a theoretical framing of food insecurity, it has not, to date, examined the food aid resources and outlets that address food insecurity at the neighbourhood level.

Largely, this is because food banks, and emergency food aid outlets more generally, are charity and third sector run - as opposed to commercial retail outlets meaning that they have tended to fall outside the remit of current food environment research. However, as the

\footnotetext{
* Correspondence: claire.thompson@lshtm.ac.uk

${ }^{1}$ Department of Public Health, Environment and Society, London School of Hygiene and Tropical Medicine, 15-17 Tavistock Place, London WC1H 9SH, UK

Full list of author information is available at the end of the article
}

food aid sector grows and diversifies, the distinction between not-for-profit and for-profit retail is blurring with subsidised food retail in the form of social enterprises - businesses that reinvest revenue into their organisation and/or the community to tackle social problems [4]. Popular not-for-profit retail formats include community-run shops and social supermarkets that make surplus and donated food available cheaply to those on very low incomes. There is also increasing crossover between food aid and for-profit food retail in the form of corporate social responsibility practices such as regular donations from large non-food companies and commercial supermarkets sponsoring and supporting the set-up of social supermarkets and acting as donation points for food banks.

These developments have yet to be integrated into macro models and concepts of the food environments. Such an undertaking is vital because the provision of food aid is rising in the UK and elsewhere [5] and the increasingly chronic nature of food poverty for vulnerable groups has made the issue a 'public health emergency' [6]. While food banks and other food aid outlets undeniably play a vital role in alleviating acute food insecurity, they are limited in their capacity to improve overall diet due to their provision of long life pre-packaged and processed foods for short-term alleviation of hunger [7]; in the United Kingdom most food banks limit clients to three visits each year, providing at most three days of

(c) The Author(s). 2019 Open Access This article is distributed under the terms of the Creative Commons Attribution 4.0 International License (http://creativecommons.org/licenses/by/4.0/), which permits unrestricted use, distribution, and 
food at each visit. If current food insecurity trends continue then the diets of low-income people may become characterised by the inclusion of significant amounts of donated and surplus food accessed via the third-sector. Developing ways of categorising and classifying food aid outlets and their services is therefore an important extension of health research that characterises and operationalises the contemporary food environment.

In order to fully understand contemporary dietary practices in the context of rising food poverty and an increasing reliance on food aid, a more holistic approach to characterising low-income food environments is needed. Such an undertaking is not without its challenges. The United Kingdom has yet to implement a national measure of household food insecurity like those used in Canada and the United States [8]. Thus far, attempts to pass a bill to that effect have yet to be successful. In which case, reliance on estimates of food insecurity based on factors such as the prevalence of food banks, the number of food parcels they distribute, and mapping populations at higher risk of food poverty as proxy measures is main the current approach [8].

Further challenges arise with regard to identifying food aid outlets. While the Trussell Trust, the United Kingdom's largest food aid franchise, has data on its food banks and the number of food parcels they distribute in the public domain, efforts to create a directory of the varied non-Trussell Trust and independent food aid outlets in the United Kingdom are still ongoing (since 2017) [9]. Various third sector organisations have developed localised 'food maps' and subsidised food outlet directories. But these tend to be produced on an ad-hoc basis and not collated centrally by government (national or local). Progressive projects at the Local Authority level, mostly by Public Health teams, have been implemented to generate a more comprehensive picture of their local food environments - recording both retail and food aid outlets in recognition of the fact that residents on low incomes routinely use both (see [10] for a United Kingdom-based example of this).

Academic collaboration with local public health teams on such projects would be an appropriate way to expand the research agenda of food environments research while supporting the already overstretched local government teams. Working with local government and health teams to characterise neighbourhood food environments and measure food insecurity risk has been instrumental in developing methods and recommendations for national level approaches [8]. The logical next step is to combine these concerns and work collaboratively towards innovative ways of capturing and understanding local food environments (including food aid outlets) that can be used to inform food environments research more broadly. In addition, this work can inform provisioning of local food aid resources, as the responsibility of addressing household food insecurity is now held by these local government teams.

Food aid - in all its evolving forms - is embedded within both local food and welfare systems and is symptomatic of the broader trend of state retreat from the provision of welfare services. Concerns of food 'access', 'choice' and 'affordability' take on new meanings in this context, especially for this part of the 'hidden' food environment that requires membership fees, access via referral vouchers, pay-as-you-feel options, or very limited opening hours. Rethinking these concepts is necessary in order to generate knowledge of how the food aid and food banking environment influences the food practices of low income populations. Developing ways of capturing and understanding this expanded conceptualisation of the local food environment is necessary in order to both help build an evidence base to challenge policies that exacerbate the drivers of food insecurity and to inform interventions aimed at improving the diet of the most disadvantaged populations.

\section{Acknowledgements \\ The first author is supported by the Wellcome Trust on a Society and Ethics Research Fellowship (Grant number: 108628/Z/15/Z). Claire Thompson is supported by a Wellcome Trust Society \& Ethics Fellowship (Grant number: 108628/Z/15/Z) \\ Funding \\ The first author is supported by the Wellcome Trust on a Society and Ethics Research Fellowship (Grant number: 108628/Z/15/Z).}

\section{Authors' contributions}

The first author produced the first draft. All authors commented upon, contributed to and edited subsequent drafts. All authors read and approved the final manuscript.

Ethics approval and consent to participate

Not applicable as this is a commentary and does not report research findings.

Consent for publication

All authors consent to publication. As this is a commentary, there are no participant consents for publication required.

\section{Competing interests}

The authors declare that they have no competing interests.

\section{Publisher's Note}

Springer Nature remains neutral with regard to jurisdictional claims in published maps and institutional affiliations.

\section{Author details}

'Department of Public Health, Environment and Society, London School of Hygiene and Tropical Medicine, 15-17 Tavistock Place, London WC1H 9SH, UK. ${ }^{2}$ Department of Geography and Environment, University of Southampton, University Road, Southampton SO17 1BJ, UK.

Received: 19 October 2018 Accepted: 26 December 2018 Published online: 07 January 2019

\section{References}

1. Swinburn B, Dominich CH, Vandevijvere S. Benchmarking food environments: experts' assessments of policy gaps and priorities for the New Zealand government. Auckland: University of Auckland; 2014. 
2. Osorio AE, Corrandini MG, Williams JD. Remediating food deserts, food swamps, and food brownfields: helping the poor access nutritious, safe, and affordable food. AMS Review. 2013;3(4):217-31.

3. Brown DR, Brewster LG. The food enviornment is a complex social network. Soc Sci Med. 2015;133:202-4.

4. Richardson M. Social enterprise in the UK: developing a thriving social enterprise sector. London: British Council; 2015.

5. FEBA. Poverty and food waste: key facts in Europe. 2018 [cited 2018 29.9.18]; Available from: http://www.eurofoodbank.org.

6. Loopstra R. Rising food bank use in the UK: sign of a new public health emergency? Nutr Bull. 2018;43(1):53-60.

7. Bazerghi C, McKay FH, Dunn M. The role of food banks in addressing food insecurity: a systematic review. J Community Health. 2016;41(4):732-40.

8. Smith D, et al. Identifying populations and areas at greatest risk of household food insecurity in England. Appl Geogr. 2018:91:21-31.

9. Goodwin, S., Food poverty, what we don't know, in End Hunger UK. 2018. http://endhungeruk.org/food-poverty-dont-know/.

10. Nzuza N, Duval D. Royal Borough of Greenwich Food Poverty Needs Assessment. London: Royal Borough of Greenwich; 2016.

Ready to submit your research? Choose BMC and benefit from:

- fast, convenient online submission

- thorough peer review by experienced researchers in your field

- rapid publication on acceptance

- support for research data, including large and complex data types

- gold Open Access which fosters wider collaboration and increased citations

- maximum visibility for your research: over $100 \mathrm{M}$ website views per year

At BMC, research is always in progress.

Learn more biomedcentral.com/submissions 